\title{
The Role of Storytelling at the Intersection of Transformative Conflict Resolution and Peace Education
}

Lloyd Kornelsen

This article explores the intersections of transformative conflict resolution and peace education through storytelling. By recalling stories from practice, I find that both peace education and transformative conflict resolution happen when people are free to "look and see" and that "looking and seeing"-as well as positive, I-Thou relationships that exhibit mutual subjectivity - are facilitated by storytelling, which is predicated on both imagining hopeful perspectives and engaging in dialogue. My concluding story demonstrates that educating for peace and facilitating conflict transformation may be fluid and perpetual. That is to say, there is not always a "happily ever after."

\footnotetext{
have worked as a peace educator for more than twenty-five years, teaching high school and university students, developing and writing curricula, and administering international internships and practicums. At the same time, I have served as a group conflict consultant for diverse local and national firms, mediating, facilitating, and training management teams. Over the years, I have come to realize that educating youth for peaceful global perspectives has a lot in common with helping management teams transform workplace conflicts. Mostly, I have learned
} 
this through student and participant stories I encountered in both classrooms and boardrooms. These stories revealed multiple intersections and overlapping purposes of peace education (PE) and transformational conflict resolution (TCR) and spoke to both interpersonal and global concerns. By interweaving the stories with scholarly literature, this article explores several of PE's and TCR's most compelling and symbiotic connections. Before I begin, however, I would like to note several qualifications.

First, the intent of this article is not to provide a definitive or exhaustive analysis of either peace education or transformative conflict resolution or even to recommend a particular course of action for practitioners of either. Rather, this paper acknowledges several of the two methods' common objectives and means of achieving those objectives-their intersections-that emerge and become apparent through the stories. Moreover, the stories are limited to my remembrances. Thus I do not follow up with a thoroughgoing analysis of all that they might mean, nor do I provide recommendations for practitioners of peace education or transformational conflict resolution. To attempt to do so would be presumptuous given that I am dealing, not with raw data, but rather with what I have perceived, remembered, interpreted, or believed was signified.

Second, Ryan points out that conflict transformation ideas and levels of analysis are interrelated and broad ranging (e.g., liberal or Marxist; personal, relational, or structural), and when discussing the concept, we must pay credence to all perspectives. Certainly personal, relational, and structural conflicts affect one another, and different ideological standpoints affect how one sees. For example, unjust economic structures contaminate interpersonal relationships, and violent interpersonal relationships affect personhood and identity. A Marxist might focus on the former, a liberal the later. Ryan's argument notwithstanding, for the purposes of this paper, when discussing TCR I do so in the personal and relational tradition of Curle, Galtung, Bush and Folger, and Lederach.

Third, Brunk, in discussing the central precepts of peace education, differentiates among three ways of conceiving PE: educating about peace, educating for peace, and peace through education. Again, notwithstanding the obvious interrelatedness of these three processes, when discussing PE, my focus will be education for peace. 


\section{A Common Purpose}

Transformational conflict resolution as an approach to conflict and as a topic within conflict studies arose about fifteen years ago as a reaction to the perceived stultifying objectives of the ideology of conflict management (Dukes). According to a number of peace researchers (Bush and Folger; Galtung, Peace by Peaceful Means; Lederach, Preparing for Peace), conflicts-interpersonal, intergroup, and systemic - are generally not resolved once and for all; hence processes of conflict resolution are more accurately characterized as "transformational." As Galtung says, you transform conflict so that "parties can live with them; you do not solve them" (Transcend and Transform viii).

The question is, Exactly what gets transformed, and to what does it get transformed? For the what, there are many offerings in the TCR literature: actors, issues, rules, and structures. Most commonly, however, the transformation is understood to relate to changes to persons, relationships, and structures (Mitchell). According to Mitchell, transformation that deescalates conflict typically involves an increase in empathy and decline in stereotyping, dehumanization, and demonization. Moreover, Bush and Folger argue that transformation should lead to a marked sense of empowerment and capacities for recognition or responsiveness to others. Lederach (The Little Book of Conflict Transformation) agrees. Conflict transformation, he says, is rooted in relational perspectives, or, put another way, relationships are at the heart of conflict transformation. Conflict resolution involves changes in the perspective from which we look at, and see each other and the conflict, to one that views peace as centered and rooted in the quality of relationships. Transformational peacemaking, he says empowers and nurtures mutuality. Finally, TCR should not be seen as fixed and having a finite end but as ongoing and evolving, cultivating perspectives and relationships that foster peace. In TCR, that is to say, there is no "happily ever after."

The current peace education movement emerged during the Cold War, when peace was mostly defined as the absence of war and violence (Pike). In the 1970s, Adam Curle began using positive language when talking of peace, understanding peace not only in terms of absence, but in terms of presence-specifically, the presence of mutually supportive relationships (Brunk). Galtung (Peace by Peaceful Means) introduced the phrase "positive peace," defining it as "presence of freedom and equity, reinforced with dialogue, integrations, solidarity and participation . . . it includes mutuality, cooperation, harmony" (32). The shift in perspective from 
negation to presence is evident in UNESCO's recently published peace education guide, Learning to Live Together (Sinclair). Quoting the UNESCO constitution, "Since wars begin in the minds of men, it is the minds of men that the defenses of peace must be constructed" (8), Sinclair states that peace is not just an absence of war but also a positive practice that begins in thought processes. What is more, this must be peace education's primary concern: facilitating the transformation of thoughts. Blumberg agrees, asserting that "peace education is critical for transforming the thinking and values of students" (31). But again the question is, Transformation from what to what? Based on a survey of peace education programs, Biton and Salomon see $\mathrm{PE}$ as cultivating greater tolerance of the other side, weakened stereotypes, weakened prejudices, and humanization of the Other, with a view to establishing (or moving toward) Galtung's notions of positive peace, which includes participation, cooperation, harmony, and mutuality.

It seems from a cursory review of the literature that TCR and PE share a deeply intertwined objective, most basically and briefly transformations in thought processes-increases in a sense of agency and empathy and declines in stereotyping, dehumanization, and demonization-so as to foster relationships of greater harmony, participation, and mutuality. Diamond agrees but sees the relationship between TCR and PE as more intimate. "To transform conflict," she says, "is to discover peace" (1). In other words, as I learned from my experiences in the field, transformational conflict resolution is pedagogy for peace.

One of my basic objectives in my work as a peace educator has long been to help students in classrooms brimming with differing worldviews and individual identities "see" and understand one another. Often, this means shaking off stereotypes, prejudiced chauvinism, misunderstandings, and fear of the Other. I believe that student achievement of these goals in the classroom-ultimately seeing each other as fellow human beings amid diversity and difference-has implications for their peaceful "being" in the world, an existence that is empowering and open to diversity, providing a sense of common global purpose or mutuality.

In my work as a mediator of group conflicts, my objectives are similar. In rooms filled with intensely conflicting individuals - that is, fearful people making the most negative of attributions of each other-I try to help participants overcome their preconceived notions-demonizing, stereotyping, chauvinism, misunderstandings-and see each other as fellows so they can get on with one another, work together, and be able to live with their conflict.

Although as both mediator and educator my basic objectives are similar, and I 
have witnessed conflict transformations in both the classroom and the boardroom, the two roles should not be conflated. The former focuses on the particular; the latter addresses the general. But the point is that to do each well-educate and mediate-an aspect of each informs the other, and in both instances that means getting people to "see" one another. On the one hand, in order for conflicts and relationships to be transformed, conflicting individuals need to be educated about the Other, confronting their own stereotypes, chauvinism, misunderstandings, and fears. One of the most enduring methods with which to teach peace, on the other hand, is to expose students to conflict transformation, causing them to become aware of their own stereotypes, chauvinism, misunderstandings, and fear of the Other. (As a related aside, according to Blumberg, overcoming the documented psychological phenomena of demonizing and dehumanizing others is the central challenge of PE. Mitchell, interestingly, says the same of TCR.)

In short, my work experience underscores the notion of shared PE and TCR purposes, and it accentuates Diamond's assertion that to "transform conflict is to discover peace" (1). It should be noted, however, that scholars in the PE and TCR communities raise contentions about the end goals of both, PE and TCR. Brunk, for example, has reservations about a universal agreement on the value and attitudinal objectives of peace education. Moreover, Ryan, speaking of transformational conflict resolution, doubts there is a normative consensus around what needs to be transformed. Granted these issues are somewhat tangential to the question-focusing as it does on the current intersections in the fields of $\mathrm{PE}$ and TCR-nonetheless the contentions should be noted. An exploration of common approaches and practices may enlighten the values of $\mathrm{PE}$ and the ends of TCR. As Galtung says, and Lederach often repeats, "the kingdom is in process." In this instance, a better understanding of the universal purposes of PE or of the normative ends of TCR may be informed through the process of exploring what educators for peace and facilitators of conflict transformation do and where the intersections of their practices lie.

\section{Intersecting Practices and Approaches}

Returning to my classroom and boardroom experiences, when transformations have occurred, it seems that rarely have they been directly linked to anything that I, as teacher or mediator, have said. In other words, transformations have 
not transpired from being told didactically "You should understand each other" or that "The world would be a more peaceful place if people understood each other." Rather, it was something in the environment or in the way in which we approached the topic or issue that liberated participants/students to "look and see." I agree with Lederach's statement in The Little Book of Conflict Transformation that "conflict transformation is more than a set of specific techniques; it is a way of looking as well as seeing" (9). And it is this that I wish to explore, and this is where I believe exist some of the most compelling and effective means of achieving the most pressing purposes of PE and TCR: those approaches that free both disputants and learners to look and see-themselves, each other, and the conflict-in a way that engenders peace and conflict transformation. What is more, I believe that they are all related to storytelling.

According to the literature of TCR and PE, approaches that facilitate "looking and seeing" cluster around the practices of (1) telling stories, (2) facilitating hopeful perspectives, and (3) practicing dialogue. The balance of this paper will examine each practice: what it is, what is "transformed," how it is so, and-perhaps most important-how they are related. But first, a story.

Many years ago, I taught a grade 12 world geography class that met in evening sessions. One evening, we were discussing global migration and Canada's responsibilities in the global refugee crisis. I posed a question: Should the Canadian government take the stance, implied by a speech of former Prime Minister Pierre Trudeau, that, since we are all neighbors, Canadians owe as much to children who sift through garbage landfills in Mexico City as they do children in Canada? The question led to a spirited and intense debate. Many students were opposed to the idea, believing that Canada should look after its own first and not worry about people beyond our borders. At the break, a student named Rami asked whether she might tell the class her story when class resumed.

Rami told us that she had come to Canada four years earlier from a refugee camp in Thailand. She had been born in Laos, but when she was ten her family fled the country because the government had made it impossible for her father to earn a living. After spending four harrowing years in a Thai refugee camp watching friends of hers die, her father became acquainted with a Canadian aid worker. The aid worker introduced him to a Canadian consulate official who arranged for the family to immigrate to Canada. That was four years earlier. Meanwhile, Rami's remaining friends were still in the refugee camp, waiting for some country to accept them. She missed them terribly. 
The class was very quiet; we were all moved. The tension that had animated the debate earlier evaporated, and strident debating positions vanished. The room seemed filled with dissonance. (Some readers might say that what the class felt or experienced was a sense of guilt; however, I think it was more akin to what Greene, in Releasing the Imagination, and Mezirow say often presages transformational learning: a disorienting life experience or an experience of startling unexpectedness, leading to a sense of cognitive dissonance.) Rami was "one of us"; she was gregarious, spoke English flawlessly, and laughed a lot. Everyone loved her. No one had thought of her as "different," as not our "own," as a "refugee" or a "type," and yet her life and her story were those of the refugee "Other," the type we had had just talked about before the break. Rami was one of us, a part of our community of "evening learners," and yet she was a refugee from far away, from a country whose culture, language, and history were different from "ours." She was a refugee whose story was immersed in values and needs we all knew-security, freedom, peace, and a love of friends and family. What were we to think? The world was no longer neatly divided between Canada and the Rest, between Us and Them. I do not honestly think any of us ever again saw images of refugees and refugee camps on TV without seeing Rami, who was one of Us.

Adult educators Merriam, Caffarella, and Baumgartner describe transformative learning as a dramatic and fundamental change in the way we see ourselves and the world in which we live. Galtung in Peace by Peaceful Means describes the process of transformational conflict resolution as making the subconscious conscious, thereby liberating people from protracted structural and direct violence. Both of these appear to have happened that night. What is more, how the students responded to Rami's story demonstrates what I mean by "looking and seeing." Students" view of themselves and their world changed, and "violent" ${ }^{1}$ and unconscious assumptions and Other-ing perspectives, embedded in their culture, geography, and ideology, were made conscious. The story freed students to see refugee Others as humans like themselves and consequently to include more Others in their community and respond to the world "out there" with greater empathy. In short, it changed the way people saw others, and so it empowered and nurtured mutuality and community. The particular informed the general; TCR became a pedagogy of peace.

Rami's approach also informed the three common approaches to TCR and PE identified above: First, she told a story, giving voice to her lived experience, and it was this to which students responded with a sense of intersubjective 
understanding (Senehi). Second, Rami would not have thought to tell her story had she no hope in changing minds or perspectives; she was able to "imagine a hoped for future" (Boulding, Cultures of Peace). Third, Rami felt free to ask her teacher to tell the story, and confident enough to tell it; in other words, she was able to "name her world" (Freire).

\section{Telling Stories: From Separateness to Intersubjectivity}

Storytelling has been vital to human society for millennia as a means of knowledge construction, communication, and myth- and meaning-making. In a complex world, Senehi says, storytelling is a universal way humans deal with knowledge, construct meaning, and interpret social relationships. Because of their universality, stories translate well across cultures. For this reason, she asserts, narratives, stories, and storytelling have the potential to enhance peace and transform how people in conflict view themselves, one another, and their conflicts. I look at three ways in which storytelling may foster personal transformation and further the ends of both TCR and PE.

The first has to do with engendering intersubjective awareness and mutual recognition. Belden Lane says that "[stories] are the only way to get at subjectivity, to get at the heart of the human person" (Senehi and Byrne 340). As Rami's approach demonstrated, her story evoked a depth of understanding and a personal connection to her and all disembodied refugees that other more didactic and abstracted means might not. Her story inspired the class to see and experience her on Buber's I-Thou terms, relating to her in "mutual presence." Moreover, because the story, through Rami, personified all refugees, the stereotype of the refugee Other became humanized, someone with whom we could relate. This was a transformation of thought, made possible through a story.

In talking about how stories address disrespect and dehumanization of the Other, however, Senehi and Byrne caution that

it is important to note that "mutual recognition" does not refer to a universalizing view where one party embraces another party as essentially the same as itself, but rather it refers to a struggle to articulate and examine differences. While developing understanding across boundaries of cultural difference may never be complete or unproblematic, it seems that trusting relationships require a 
desire on the parts of all parties to recognize the dignity and experience of the other. $(240-41)$

In other words, the mutual recognition that is elicited by story is one of intersubjective awareness (Kellet and Dalton), which fosters trust and compels one to offer dignity of personhood to another and to begin seeking an understanding of difference.

Another example of mutual recognition through story was recently demonstrated by a student in my "Introduction to Conflict Resolution" class. Mike was a bright, informed, and well-spoken Jewish immigrant from Argentina. His grandfather had served in the Israeli military, and he was hoping to do the same some day. Mike held strong anti-Palestinian views, and he was public with his opinions, arguing his points intelligently and articulately and sometimes quieting and intimidating his classmates. As the school year unfolded, however, Mike began getting quieter. When I asked him about it after class one day, he told me he was reading The Lemon Tree and was beginning to realize there was another perspective to the Israeli-Palestinian conflict to which he had never given conscious thought. This realization had so shaken his view of the issue he didn't know what to think, so it was "best to be quiet."

Based on a true story, The Lemon Tree is a historical narrative spanning sixty years (Tolan). It follows the lives of two individuals and their families: Hungarian Jews who fled post-Holocaust Europe for Israel, and middle-class Palestinians who fled violence in Israel for the West Bank. In alternate and juxtaposing chapters, author Sandy Tolan tells the stories of Bashir and Dalia as they make their way in the world amid circumstances beyond either's reach or control. Tolan gives voice to both parties and does so with no apparent sentiment or judgment, political, ethical, or otherwise. Dalia and Bashir meet in 1968 and continue to meet, albeit sporadically, to this day. Their personal conflict-she lives in the house from which he and his family were forced to flee-is almost totally contaminated by the larger Palestinian-Israeli conflict and is never resolved. Still, they keep meeting.

To paraphrase Mike:

What shook me was that for the first time in my life, I read a Palestinian story from a Palestinian perspective and felt empathy. I was able to empathize because it was just that, a story, without any implicit political message, and because of that, it caught me unaware. I still haven't changed my mind on Israel, and I'm still 
a proud Jew, and I've still got problems with aspects of the Palestinian agenda. But now I can't help but know there is another story-meaning there is another human experience to which I must respond and recognize and acknowledge.

I spoke with Mike again last month. He still struggles deeply with reconciling his newfound perspective with his old, which is perhaps an emotional residue of perspective transformation. Mike has been accepted into the Munk Centre for Peace and Conflict Studies at the University of Toronto. He plans to spend the summer researching the Palestinian perspective in the Mideast conflict, not because he has changed sides, but because he wants to engage his Palestinian student colleagues in "respectful and intelligent discussion."

Mike's experience illustrates how stories may cultivate intersubjective awareness, inspiring greater empathy and mutuality. It also reflects Kellet and Dalton's point that the enhanced awareness wrought by hearing another's narratives leads to more choices about conflict practices. A year ago, Mike could not have envisioned exploring the Palestinian perspective or even that there was one worth exploring. His story demonstrates "that 'mutual recognition' does not refer to a universalizing view where one party embraces another party as essentially the same as itself, but rather it refers to a struggle to articulate and examine differences" (Senehi and Byrne 240). In spite of his desire to engage Others in dialogue, Mike still clearly sees himself, his identity, his history, and culture as different and worthy of protection. And herein lies a second benefit of storytelling: it is a means of finding and giving voice to one's identity and dignity, while recognizing and learning of others.

In The Moral Imagination, Lederach says that "there is a sense in which the whole of peace-building could be summed up as finding and building voice" (16). He and other local and international peace workers and researchers (Pankratz; Senehi and Byrne) see quests for and threats to identity as a primary source of interpersonal and intergroup conflict. The challenge is in finding a means to giving voice and establishing identity in a conflicting and heterogeneous world, or, as Lederach puts it in The Little Book of Conflict Transformation, "encouraging people to address and articulate a positive sense of identity in relationship to others but not in reaction to them" (55).

Greene, in "Plurality, Diversity and the Public Space," characterizes this challenge as one of individuals with "provinces of meaning" who need to overcome their silences and release their "persons" for the sake of realizing their identity and 
for the benefit of the community and world. The only way to do this, she says, is through telling and sharing their stories. Greene calls on teachers and facilitators to create spaces in which students and participants are given the opportunity, through story writing and storytelling, to express their "meanings" in a public venue. As individuals reveal their distinctiveness in the company of others, she says, they become aware of their unique identities and thus are able to imagine what it must be like to be the Other, and to be attentive to the stranger, her pain and worldview. I have witnessed this often. When students or participants share their stories and meanings, individual identities emerge and with them an ability or freedom to hear and recognize others. Greene calls this a process of "heteroglossia," where within a diversity of voices a common concern emerges, a community. ${ }^{2}$

What are the concomitant implications for TCR and PE? To cultivate a sense of mutuality across difference, one must reconcile the tension between a need for identity and voice and respect for otherness and difference. Telling our stories to one another may promote this reconciliation.

A third way in which stories may facilitate TCR and PE is by initiating introspection and reflexivity and revealing subconscious motivations and assumptions. According to Carl Jung (as discussed in Pajak), people unconsciously project their shadow selves-including negative qualities like jealousy, anger, and spite-onto others. Making the link to interpersonal conflict, Schellenberg and Wilmot and Hocker theorize that people have an unwitting tendency to attribute the cause of a conflict with which they are involved to a negative personality trait of their "opponent" and to circumstances over which they themselves have no control. Consequently, they are unable to take responsibility for the conflict or its resolution. And of course the "opponent" sees things the same way, but in reverse, so the two become stymied. Not only are these tendencies apparent in interpersonal conflict, they are often evident in media portrayals of international conflict.

Although this paper focuses on personal storytelling, it is important to note that in my experience, fictional stories like fables and fairy tales, with their rich and fantastic narratives of victim, villain, and hero archetypes, can sometimes help people see themselves even more honestly, their opponents more fairly, and the conflicting issue more objectively. There are several reasons for this. First, fairy tales are simple and familiar yet distant from the reader or listener's own real-life conflict, and so they can serve as a nonthreatening mirror of ones own projections, assumptions, and actions, making them easier to accept, 
apprehend, and respond to. Second, because it is easy to manipulate a fictional story's constructed reality-to tease out a character's vilifying and victimizing perceptions or a story's unquestioned assumptions-it becomes easier to imagine one's own conflict as constructed and malleable. Finally, when a fictional conflict is transcended, the listener experiences a greater sense of agency, freeing her to change the circumstances of her own conflict. In this way, I have seen fables and fairy tales help deconstruct difficult and seemingly intractable conflicts. ${ }^{3}$

To summarize, the practice of storytelling-whether telling our own, hearing those of others, or reimagining our own stories through fiction-furthers the TCR and PE objectives of looking and seeing. Storytelling may enhance a sense of mutuality across difference, stimulate introspection and reflexivity, and cultivate personal agency.

\section{Facilitating Hopeful Perspectives}

A few years ago, after many years of teaching a high school current history course called "World Issues," I became clinically depressed, and I took a year off from teaching to think about my future. I knew my depression was linked to teaching, but I did not know exactly how. A person close to me suggested that perhaps it had to do with the class curriculum, which was filled with the problems of the world: war, militarism, genocide, poverty, and so on. I had often worried for my students that a preoccupation with the negative, while helping them become more critically aware, might overwhelm them and leave them despairing and cynical, with no hope for a more just future. It had never occurred to me that I might be a victim, too.

One of the first things I did when I returned to teaching was to develop a global citizenship course, which included a practicum in Costa Rica. I chose that country because of its hopeful approach to development. It had no military, in a region of intense and violent conflict, and it was a leader in rainforest preservation and village cooperative development. Since then, the depression has not returned. I did not make the connection until last year. Perhaps my friend was right; maybe there is a link between the two, seeing the world bleakly and career-ending depression. If that is true, what are the implications for students of $\mathrm{PE}$ and people engaged in the work of conflict transformation?

This question is a concern of both TCR and PE. Scholars who write about 
PE, whether at the high school or undergraduate level, worry that curricula is too heavily weighted toward violent and warlike perspectives. In 1920, two years after the Great War, H. G. Wells wrote that to prevent young people from falling into despair, they needed to envision a positive future of possibilities in the world; they needed to know that war and destruction were not human inevitabilities (Shlichtman). Unfortunately, today, almost a hundred years later, a number of peace educators (Boulding, Cultures of Peace and Building a Global Civic Culture; Blumberg; Burrows; Danesh; Davies; Noddings) contend that social studies education is preoccupied with images and narratives of war, militarism, and violence. The consequence, Wendon says, is despair and inaction as students cannot imagine a preferred future. This is how she sees the current situation:

In the case of those social and ecological realities that inhibit the achievement of a culture of peace, while it is agreed that violence is abhorred, our imaginations often appear to be prisoners of the present, apparently incapable [of ] visualizing ... the long term future or of creating positive alternatives. Reasons put forth to explain this paralysis include the belief that things cannot change ... and therefore, the unwillingness to face what present realities portend. It is also true that the education system does not usually try to change such beliefs or help students acquire skills related to thinking in terms of the distant future. (161)

Wendon goes on to say that a sense of helplessness and powerlessness impedes prospects for building peace, both locally and globally.

Those who write about TCR practice voice similar concerns. Here is Mitchell:

Transformation processes should aim at removing the sense of helplessness about the conflict among participants, particularly those at the local and grass roots levels of the parties[,] and increasing the sense of empowerment, at least in terms of their being able to affect the conduct of the conflict, its resolution and the structures that originally gave rise to it. (10)

Lederach, in The Little Book of Conflict Transformation, concurs, saying that a transformational approach must begin with a positive orientation toward conflict and a willingness to engage in the conflict in an effort to produce constructive change or growth, a mindset, for example, that Rami assumed when she told her story. 
So how are these orientations and propensities to be cultivated? Boulding, in Cultures of Peace, says that the place to start is to counter fear-laden and fatalistic images and offer students specific images of hopeful possibilities and futures. Liebler and Sampson agree, arguing from the standpoint of Appreciative Inquiry that people move invariably toward the expectations and images they create. For Boulding, this means that students should know that war and warrior cultures are not biological inevitabilities. The practice of war is learned and therefore can be unlearned; for most of history and in most places, people have lived peaceably. It becomes easier to envision a hopeful future, she says, when one has a sense of choice-knowing there are options-and when one knows that in the past, peaceful ways of living were the preferred options.

Similarly, Lederach, in The Little Book of Conflict Transformation and The Moral Imagination, looking to explain the art and soul of peacemaking, talks of the centrality of the moral imagination, describing it as "the capacity to imagine something rooted in the challenges of the real world yet capable of giving birth to that which does not yet exist" (The Moral Imagination ix). If people are to be empowered-overcoming obstacles and moving from "I cannot" to "I can"-then the imagination and ideas of a desired future must be based in what is real and true. What practice might do this? According to Lederach (The Moral Imagination), in an ideal world, "[peace educators and facilitators of TCR] would be chosen for their life stories of how they overcame what seemed insurmountable odds to break out of injustice and threat without resorting to violence" (177).

McIntosh, moreover, talks of a need for holistic role models. She emphasizes the importance of acquainting students with people in history whose character traits are most needed in the world today: care, openness, and compassion. Calling them "menders" of society, McIntosh says, these are the women and "lower caste" men whose stories are mostly absent from modern-day consciousness and collective historical memory. The stories of these exemplars can inspire students to holistic ways of thinking and being as they offer concrete and positive examples of societal mending tools and skills.

In sum, both PE and TCR call for approaches that help people move from despair to hope, from helplessness to empowerment and participation. A basic way of doing so is by offering real and hopeful perspectives and by unveiling heretofore unimaginable options for action and living. It is this capacity for imagining alternatives to violence that is promoted through storytelling.

Jon was a student in my grade 12 "Peace and Development Studies" class a 
few years ago. The first six weeks of the course are devoted to conflict and conflict resolution theory-the ideas, principles, practices, and issues. One day, we were discussing Schellenberg's attribution theory when Jon, a recent refugee from Kosovo, came to me after class, very excited. He had made a connection between this idea-attribution theory-and the interethnic Serb-Kosovar conflict of which he had been a part. He had to go back, he told me, to tell his family and friends about these "new" ideas.

Over the winter break, Jon got himself invited to speak at his former high school in Kosovo. The audience he spoke to was composed of fellow Serbs, students, teachers, and parents. He talked about how everyone sees the world differently, through a lens filtered by their own history, stories of their culture and upbringing, and if Serbs were ever to live peaceably with Kosovars, they would need to understand their worldview and try to imagine how they, the Kosovars, saw the Serbs. (Jon was able to say this, and believe it, even though Kosovars had killed his older brother.) According to Jon, many young people in the audience appeared to understand what he was saying; they were excited, as if some ancient truth had been revealed. Others were not so pleased, seeing him as a traitor. But the point is, Jon was acting in the world to help facilitate intercultural understanding and mutuality. He was able to so do because he had come to imagine a hoped-for future and had discovered the tools/options/mindset to help create it.

It is important to note that Jon's "transformation" was not brought about by me, the teacher, telling him how to think, behave or see the world. It was Jon who, from a class discussion on conflict derived (or looked and saw) implications for his own life and for a conflict of which he was a part and recognized options he had not seen before. Jon's actions also, I believe, demonstrate an agency and potential capacity for action that we all hold. What we educators of peace and facilitators of conflict transformation can do is provide the circumstances within which that agency may be apprehended and actualized-knowing that agency can only be realized in freedom (see Dewey). This informs a third intersecting approach of TCR and PE: the practice of dialogue.

\section{Practicing Dialogue (From I-It to I-Thou)}

Fundamental to both TCR and PE is the practice of dialogue. While there are numerous gradations of the term in the scholarly literature, Bohm contends that, 
in its essence, all communication is dialogue - a stream of meaning flowing among, through, and between people, out of which emerges a common understanding. The notions of dialogue articulated by Buber and Freire are seminal, each offering a unique perspective on the concept and informing a common practice of $\mathrm{PE}$ and TCR.

Buber (Between Man and Man) portrays dialogue as both a type of communication and a kind of relationship, both a process and a goal that are characterized by openness, directness, mutuality, and presence. Genuine dialogue, he says, means experiencing the other side of the relationship and thinking in a way that includes "orienting ourselves to the presence of the other person" (33). This approach recognizes the other's freedom, and in this fullness of communication, Buber states, "I turn to my beloved in his otherness, independence and self-reality with all the intention of my heart" (xv). To Buber, this is what it means to communicate with another human being, a Thou, a Subject.

What this approach may mean for peace building is most compellingly observed by Boulding (Building a Global Civic Culture). She contends that human beings have two conflicting desires: one for autonomy and independence, the other for bonding and realizing completeness in the other. Peace happens when people relate in a way that at once respects both needs. In Buber's conception of I-Thou communication (dialogue), Boulding finds a way of doing just this:

In the I-Thou relationship we stand in openness before the Other (any other with whom we have to do) and let that Other be in all their wholeness and uniqueness. We may not measure, define, or utilize the other person. We may only relate. We meet the other person. The event of meeting lies in the between-ness, in the space that must reverently be left there, between one Being and another. (146)

When this occurs, says Boulding, we find commonality amid diversity, and we discover peace amid the tension between a need for separateness and a need for belonging. Meeting is an act of freedom and an experience of mutuality and a place of peace.

Freire defines dialogue from a critical perspective, in the context of student-teacher relationships. According to him, the ontological vocation of human beings is to become human, to be able to name the world and change it. It is an educator's responsibility, he says, to help facilitate this human becoming, to help students move from being Objects who are alienated from the world, to being 
Subjects who are participants in the world. Since no one can unveil the world for another, however, this feat can only be accomplished through dialogue: "an encounter between two people, mediated by the world in order to name the world" (88). Dialogue by its nature and purpose is a practice of freedom and mutuality; its goal is to have participants gain the confidence and ability "to name their world”- as Rami did-to be free and autonomous Subjects. Dialogue contains within it both an end and a means, cultivating a sense of autonomy and agency by communicating with another as an autonomous Subject. What, then, are the implications for peace and conflict transformation? According to Freire, war and violence are rooted in oppression. When pedagogy is a practice of freedom (i.e., dialogue), there is no objectification or oppression, and there can be no war or violence. A culture of peace is restored, both interpersonally and systemically.

Storytelling is the ultimate expression of the $I$-Thou relationship, relying as it does on the cocreation of storyteller and listener to develop any given storytelling event. Unlike theater, there is no fourth wall in storytelling; thus the audience is the teller's partner, providing verbal and nonverbal cues that help shape the finished product.

\section{Conclusions}

In this paper, I have reiterated the impotence of a teacher's/facilitator's nonnarrative verbal entreaties, how transformation cannot be compelled, only transacted (Kornelsen, “Teaching with Presence”). As Freire's pedagogy assumes and Buber's I-Thou relationship alludes, however, it is through imagination and dialogue that teachers and facilitators can affect the mutual objectives of PE and TCR, if dialogue is indeed a practice of peace, and one that furthers its own ends. In other words, if a teacher/facilitator assumes a peaceful stance and dialogues with students/participants, peace is fostered. (As Mitchell asserts, "Conflict transformation can stand both for an end state when the conflict can be viewed as "transformed" and for a set of processes through which the end state is achieved" [4].) Teachers/facilitators, wittingly or not, set tone, make decisions about power and power sharing, and help determine the nature of the learning/facilitation space. Their approach and way of being with others ripples through the learning or conflicting group: dialogue engenders dialogue; peace fosters peace. ${ }^{4}$ However, a caution: 
To teach/facilitate dialogically can be exhausting, mentally and emotionally, and discouraging. 5 It becomes tempting to resort to top-down, technique-driven teaching/facilitating (Senyshyn; Walck). But this is not dialogue, and Senyshyn says it denies our humanity and that of our students. Bohm says that methods and techniques have a tendency to disempower participants, while Freire calls a topdown approach "banking education," saying that it objectifies and disempowers learners. Buber (Between Man and Man) says that it is demonic to "proceduralize" dialogue. In short, for dialogue to be dialogue, one must be present, open, mutual, and direct (see Buber). According to Freire and others (e.g., Kornelsen, "Teaching with Presence"), to teach and facilitate this way, day in and day out, requires unflinching commitment and love. This has implications for curricula, systems of education, and methodologies of conflict resolution, all of which are outside the purview of this discussion.

To summarize, dialogue as conceived by Buber and Freire is a vital practice of PE and TCR. At its core, dialogue is communication that fosters and assumes agency, voice, and mutuality; it is an act of freedom and an occasion of intersubjective meeting. It is an expression of Bush and Folger's goal of conflict transformation: empowerment and a capacity for recognition or responsiveness to another. Dialogue can be taken as a means to, and an end for, TCR and PE. It fosters not looking and seeing so much at it is looking and seeing. Teachers and facilitators are critical to fostering its practice.

Storytelling, PE, and TCR have common objectives and share interrelated practices and approaches. In fact, it has been said one is pedagogy for the other. Sharing stories, which can accentuate positive perspectives and promote engagement in dialogue, stimulates transformation of thought processes-increasing a sense of agency and empathy and decreasing stereotyping, dehumanization, and demonization - so that relationships of greater harmony, participation, and mutuality are fostered. Put another way, practices that are common to TCR and PE stimulate looking and seeing-that is, "liberating the subconscious" - in a way that fosters the mutual objectives of TCR and PE.

Even though transformations cannot be compelled by a third party, an abiding commonality for PE and TCR is the critical role a person-a teacher, facilitator, educator, or peace worker-plays in cultivating the circumstance and environment for transformation and learning. Many years ago, near the beginning of my teaching career, a former student came asking for advice. Hashmi, an immigrant from Pakistan, was deeply troubled. The previous week twelve members of his 
extended family had been gunned down on a highway in northern Pakistan. He felt he needed to go back, but his mother, back in Pakistan, was desperate for him not to return. He wanted my advice: What did I think he should do? I asked why his mother did not want him back in Pakistan. He paused, looked down, and quietly said, "Mr. K, I am someone who Canadians might call a terrorist; I was in a group fighting for our religious rights; we kidnapped, fire-bombed buses, used AK-47s.... I was a wanted man in Pakistan. My mother, because of her position, was able to get me out of the country before I was caught."

I was dumbstruck; Hashmi seemed to me to be the antithesis of a violent person; he was respectful, soft-spoken, and courteous to a fault. I asked him how such a "good" person could do such violent things. What he told me has lingered for twenty years. He said, "I'm two different persons. In Canada, I am the person you see; I can't imagine hurting anyone; in Pakistan I am different, I change, and my mom knows that, and this is why she doesn't want me back. I can't explain it, this change; it just happens. Maybe it has something to do with the air, the spaces, the culture, the schools, what I experience in these different places. I don't know ..."

I do not know what ever became of Hashmi. But his story, his confusion about how he could be two different persons, one violent and one peaceful, depending on where he lived, speaks to the consequential impact of the social/ cultural environment on people's disposition for peace or violence and of the provisional nature of peace and conflict transformations. It also raises questions for those concerned with education, peace building, and conflict transformation, questions about the various factors that influence people and shape their life choices and predilections. But most significantly for practitioners, it provides an approach to educating for peace and facilitating conflict transformation that is ongoing, fluid, and perpetual, one that, as Freire states, views the world not as being, or arriving, but as becoming. There may be no "happily ever after," but at least the stories help show us the way.

Lloyd Kornelsen lives in Winnipeg, Canada. For the past twenty-five years he has worked in the field of education as a high school and university teacher and administrator, developing curricula, facilitating practicums, and overseeing international internships in global citizenship and peace studies. In addition, he has served as a conflict resolution consultant for numerous firms, profit and nonprofit, national and international. Upon completing his 
PhD this year, he won the Manitoba Education Research Network award for outstanding achievement in education research in Manitoba.

\section{WORKS CITED}

Barseh, H. B. “Education for Peace: The Pedagogy of Civilization.” Addressing Ethnic Conflict through Peace Education. Ed. Z. Bederman and C. McGynn. New York: Palgrave Macmillan, 2007. 137-60. Print.

Biton, Yifate, and Gavriel Salomon. (2006). "Peace in the eyes of Israeli and Palestinian youths: Effects of collective narratives and peace education program.” Journal of Peace Research, 43.2 (2006): 167-80. Print.

Blumberg, Herbert H. "Education.” Peace Psychology: A Comprehensive Introduction. By H. Blumberg, P. Hare, and A. Costin. New York: Cambridge UP, 2006. 31-36. Print.

Bohm, David. On Dialogue. Ed. L. Nichol. London: Routledge, 1996. Print.

Boulding, Elise M. Building a Global Civic Culture: Education for an Interdependent World. Syracuse, NY: Syracuse UP, 1990. Print.

- Cultures of Peace: The Hidden Side of History. Syracuse, NY: Syracuse UP, 2000. Print.

Brunk, Conrad G. "Shaping a Vision: The Nature of Peace Studies." Patterns of Conflict, Paths to Peace. Ed. L. Fisk \& J. Schellenberg. Peterborough ON: Broadview Press, 2000. 11-34. Print.

Buber, Martin. Between Man and Man. Trans. R. G. Smith. London: Routledge, 2006. Print.

Burrowes, Robert J. The Strategy of Nonviolent Defense. Albany: State U of New York P, 1996. Print.

Bush, Robert A. Baruch, and Joseph P. Folger. The Promise of Mediation: Responding to Conflict through Empowerment and Recognition. San Francisco: Jossey-Bass, 1994. Print.

Capra, Fritjof. The Turning Point: Science, Society, and the Rising Culture. Toronto: Bantam Books. 1982. Print.

Curle, Adam. Making Peace. London: Tavistock, 1971. Print.

Davies, Lynn. "Schools and War: Urgent Agendas for Comparative and International Education." Compare 35.4 (2005): 357-71. Print.

Dewey, John. Experience and Education. New York: Macmillan, 1938. Print.

Diamond, Louise. "Beyond Win/Win: The Heroic Journey of Conflict Transformation.” 
Occasional Paper no. 4. Washington, DC: Institute for Multi-Track Diplomacy, November 1994. Print.

Dukes, Franklin E. “Why Conflict Transformation Matters: Three Cases.” N.d. Web. 18 February 2014. <www.gmu.edu/programs/icar/pcs/Dukes61PCS.html>. Freire, Paulo. The Pedagogy of the Oppressed. New York: Continuum, 2007. Print. Galtung, Johan. Peace by Peaceful Means: Peace and Conflict, Development and Civilization. Thousand Oaks, CA: Sage, 1996. Print.

- Transcend and Transform: An Introduction to Conflict Work. Boulder, CO: Paradigm Publishers, 2004. Print.

_ . "Violence and Peace." A Reader in Peace Studies. Ed. Paul Smoker, Ruth Davies, and Barbara Munske. Toronto: Pergamon, 2001. 3-14. Print.

Greene, Maxine. "Plurality, Diversity and the Public Space." Can Democracy Be Taught? Ed. A. Oldenquist. Bloomington, IN: Phi Delta Kappa Educational Foundation, 1996. 27-44. Print.

- Releasing the Imagination: Essays on Education, the Arts and Social Change. San Francisco: Jossey-Bass, 1995. Print.

Harper, Gary. The Joy of Conflict Resolution: Transforming Victims, Villains, and Heroes in the Workplace and Home. Gabriola Island, BC: New Society Publishers, 2004. Print.

Jarvis, Peter. “Teachers and Learners in Adult Education: Transaction or Moral Interaction?" Studies in the Education of Adults 27.1 (1995): 24-35. Print.

Kellett, Peter M., and Diane G. Dalton. Managing Conflict in a Negotiated World: A Narrative Approach to Achieving Dialogue and Change. Thousand Oaks, CA: Sage, 2001. Print.

Kornelsen, Lloyd. "Teaching with Presence." Authenticity in Teaching. Ed. P. Cranton. San Francisco: Jossey-Bass, 2006. 73-82. Print.

_ . “The Three Little Pigs: Who Was Right?” Dispute Resolution: Building the Road to Peace. The Fifth Biennial Conference of The Network. Bishop's University, Lennoxville, Quebec. May 1998. Presentation.

Lane, Belden. "Personal Communication” (1996). Senehi and Byrne. 240. Print. Lederach, John Paul. The Little Book of Conflict Transformation. Intercourse, PA: Good Books, 2003. Print.

- The Moral Imagination. New York: Oxford UP, 2005. Print.

—. Preparing for Peace: Conflict Transformations across Cultures. Syracuse, NY:

Syracuse UP, 1995. Print.

Levinas, Emmanuel. Otherwise Than Being or Beyond Essence. Trans. Alphonso Lingis. 
The Hague: Martinas Nijhoff. 1981. Print.

Liebler, Claudia, and Cynthia Sampson. "Appreciative Inquiry in Peacebuilding: Imagining the Possible." Positive Approaches to Peace-Building: A Resource for Innovators. Ed. M. Abu-Nimer, C. Sampson, C. Liebler, and D. Whitney. New York: Pact Publishing, 2003. 55-82. Print.

McIntosh, Peggy. "Gender Perspectives on Educating for Global Citizenship." Educating Citizens for Global Awareness. Ed. N. Noddings. New York: Teachers College P, 2005. 22-39. Print.

Merriam, Sharan B., Rosemary S. Caffarella, and Lisa M. Baumgartner. Learning in Adulthood: A Comprehensive Guide. San Francisco: Jossey-Bass, 2007. Print.

Mezirow, Jack. Transformative Dimensions of Adult Learning. San Francisco: JosseyBass, 1991. Print.

Mitchell, Christopher R. "Beyond Resolution: What Does Conflict Transformation Actually Transform?” Peace and Conflict Studies 19.1 (2002): 1-23. Print.

Noddings, Nel. "Global Citizenship: Promises and Problems.” Educating Citizens for Global Awareness. Ed. N. Noddings. New York: Teachers College P, 2005. 1-21. Print.

Pajak, Edward. "Exploring the Dark Side of Teaching." Journal of Curriculum Theorizing 14.2 (1998): 8-14. Print.

Pankratz, D. Personal communication. February 7, 2010.

Pike, Graham. "A Tapestry in the Making." Weaving Connections: Educatingfor Peace, Social and Environmental Justice. Ed. T. Goldstein and D. Selby. Toronto: Sumach P, 200o. Print.

Ryan, Stephen. “Conflict Transformation: Reasons to be Modest.” Handbook of Conflict Resolution and Analysis. Ed. D. J. D. Sandole, S. Byrne, I. Sandole-Staroste, and J. Senehi. New York: Routledge, 2009. 303-14. Print.

Schellenberg, James A. Conflict Resolution: Theory, Research and Practice. Albany: State U of New York P, 1996. Print.

Schlichtmann, Klaus. “H. G. Wells and Peace Education.” Journal of Peace Education 4.2 (2007): 193-206. Print.

Senehi, Jessica. "Building Peace: Storytelling to Transform Conflicts Constructively." Handbook of Conflict Resolution and Analysis. Ed. D. J. D. Sandole, S. Byrne, I. Sandole-Staroste, and J. Senehi. New York: Routledge, 2009. 201-14. Print.

Senehi, Jessica, and Sean Byrne. "From Violence toward Peace: The Role of Storytelling for Youth Healing and Political Empowerment after Conflict.” Troublemakers or Peacemakers? Youth and Post-Accord Peace Building. Ed. S. McEvoy-Levy. South 
Bend, IN: U of Notre Dame P, 2006. 235-58. Print.

Senyshyn, Yaroslav. "Perspectives on Performance and Anxiety and Their Implications for Creative Teaching." Canadian Journal of Education, 24.1 (1999): 30-41. Print. Sinclair, Margaret. Learning to Live Together: Design, Monitoring and Evaluation of Education for Life Skills, Citizenship, Peace and Human Rights. In collaboration with L. Davies, A. Obura, and F. Tibbitts. Eschborn: Deutsche Gesellschaft für Technische Zusammenarbeit (GTZ), 20o8. Print.

Tolan, Sandy. The Lemon Tree: An Arab, a Jew, and the Heart of the Middle East. New York: Bloomsbury, 2006. Print.

Van Manen, Max. “Moral Language and Pedagogical Experience.” Journal of Curriculum Studies 32.2 (2000): 315-27. Print.

Vercoe, Anaru. "The Student-Teacher Relationship in Freire's Pedagogy: The Art of Giving and Receiving." New Zealand Journal of Adult Learning 26.1 (1998): 56-73. Print.

Walck, Christa L. “A Teaching Life.” Journal of Management Education 21.4 (1997): 473-82. Print.

Wenden, Anita L. "Integrating Education for Social and Ecological Peace: The Educational Context." Educating for a Culture of Social and Ecological Peace. Ed. A. L. Wenden. Albany: State U of New York P, 2004. 145-63. Print.

Wheatley, Margaret J. Leadership and the New Science: Learning about Organization from an Orderly Universe. San Francisco: Berrett-Koehler, 1999. Print.

Wilmot, William, and Joyce Hocker. Interpersonal Conflict. New York: Mcgraw-Hill, 2007. Print.

\section{NOTES}

1. I am assuming Galtung's psychological dimension of violence: “[It] includes indoctrination of various kinds that serve to decrease mental potentialities" ("Violence and Peace," 10).

2. Chaos theorist Margaret Wheatley has written extensively on how a sense of common meaning only emerges in environments of free, open, and authentic sharing of individual and distinct voices.

3. In 1998, I presented at conflict resolution conference at Bishop's University on alternative versions of the "Three Little Pigs and Big Bad Wolf” conflict ("The Three Little Pigs: Who Was Right?"). A mediator of fifteen years for the British Columbia Institute of Justice was in attendance. He told me that of the hundreds 
of interpersonal mediations in which he had participated, all had a similar victim-villain narrative. He ended up writing a book on the idea, saying that fairy tales and fables can serve as a template for students of international conflict and mediators of interpersonal conflict to deconstruct conflicts and provide a means for introspection and reflexivity by disputants and their allies (see Harper).

4. Much has been written from the perspective of chaos theory on how the nature of a teacher's/facilitator's presence affects a learner's ability and freedom to engage in dialogue with fellow participants. Wheatley and physicists like Fritjof Capra suggest that there is compelling evidence that connections between people are more than psychological; they are in fact physical. More exploration of this phenomenon is warranted on how it affects interpersonal relationships in conflict. Suffice it to say, people tend to treat others as they are treated.

5. Here is how some people see dialogical teaching/facilitating: Peter Jarvis and Max Van Manen (basing much of their thinking on the philosophies of Buber and Emmanuel Levinas) describe it as having an ongoing openness to the call and vulnerability of the Other (Van Manen) and a continual accessibility to, and care for, the student or participant (Jarvis). Andres Vercoe argues that, to teach dialogically, teachers must always approach the same topic afresh, allowing for the potential to always relearn and recreate the subject anew with students. Lederach (Preparing for Peace) sees facilitation as a subtle balancing act between elicitingconstructing knowledge together with participants_and prescribing-introducing others' approaches and ideas. Given what it means to teach dialogically and its critical importance to educating for peace and facilitating conflict transformation, this is a vital issue that requires more research, discussion, and reflexivity. 